University of Nebraska - Lincoln

DigitalCommons@University of Nebraska - Lincoln

1929

\title{
"Triassic-Jurassic 'Red Beds' of the Rocky Mountain Region": A Discussion
}

John B. Reeside Jr.

U.S. Geological Survey

Follow this and additional works at: https://digitalcommons.unl.edu/usgsstaffpub

Part of the Earth Sciences Commons

Reeside, John B. Jr., "'Triassic-Jurassic 'Red Beds' of the Rocky Mountain Region": A Discussion" (1929). USGS Staff -- Published Research. 498.

https://digitalcommons.unl.edu/usgsstaffpub/498

This Article is brought to you for free and open access by the US Geological Survey at DigitalCommons@University of Nebraska - Lincoln. It has been accepted for inclusion in USGS Staff -- Published Research by an authorized administrator of DigitalCommons@University of Nebraska - Lincoln. 


\title{
“TRIASSIC-JURASSIC 'RED BEDS' OF THE ROCKY MOUNTAIN REGION": A DISCUSSION ${ }^{\mathrm{r}}$
}

\author{
JOHN B. REESIDE, JR. \\ U.S. Geological Survey
}

\begin{abstract}
The conclusion drawn by Professor E. B. Branson in a recent paper on the "Red Beds" of the Rocky Mountain region that parts of these beds are marine is considered likely. The conclusion that there exists no basis for subdivision of the beds is not accepted, and a division of the Mesozoic part into Lower Triassic, Upper Triassic, and Jurassic units is advocated. The conclusion that no eolian deposits are present likewise is not accepted, and the interpretation of important parts of the Jurassic unit as eolian is advocated. Disagreement is expressed with much of Professor Branson's correlation table, and a substitute is offered. His paleographic map is considered invalid because based on erroneous correlations and interpretations of conditions.
\end{abstract}

\section{GENERAL STATEMENT}

Professor E. B. Branson's recent paper on the "Triassic-Jurassic 'Red Beds' of the Rocky Mountain Region"' bears upon specific and general problems of great interest. His observations are stated to cover nearly the whole region of occurrence of red beds of Mesozoic age, and his conclusions are far-reaching. Branson presents a map showing the distribution of red beds in the Rocky Mountain region ${ }^{3}$ and a table showing his age assignments and correlations of the included formations. ${ }^{4} \mathrm{He}$ states, in summary, ${ }^{5}$ that no adequate basis is available for the separation of the lower from the upper red beds, that the vertebrate fossils known are of little value in correlation, that no appreciable part of the red-bed sequence from Permian to Jurassic is eolian in origin, and that various features of the red beds indicate a marine origin for the major part of them and a subaerial origin for other minor parts. $\mathrm{He}$ also presents a paleogeographic map of central North America in Upper Triassic time ${ }^{6}$ which shows an inland sea covering northwestern Texas, northern New Mexico and Arizona, eastern Nevada, southeastern Idaho, all of

I Published by permission of the director of the U.S. Geological Survey.

2 Journal of Geology, Vol. XXXV (1927), pp. 607-30.

3 Ibid., p. 608, Fig. I. 5 Ibid., pp. 607, 630.

${ }_{4}^{4}$ Ibid., p. 6ro, Fig. 3. $\quad{ }^{6}$ Ibid., p. 609, Fig. 2. 
Wyoming and Utah, western Colorado, southern Montana, and western Nebraska and South Dakota; a large river system draining the central United States and entering the sea in northwestern Texas; and a narrow channel in Nevada connecting with the open ocean to the west.

Such a synthesis of data pertaining to the "Red Beds" as Branson has attempted is welcome indeed, but to be satisfactory and useful it must be fairly complete and must account, in its broad view, for various local features, or at least must not stand in violent conflict with them. It is the present writer's opinion, based in part on the literature but in greater part on personal observation during fifteen summers of field work in Wyoming, Colorado, Utah, and northern Arizona and New Mexico, that at many points Professor Branson has failed to accomplish this result. Much still remains to be learned, of course, but much has been accomplished that should be taken into account in a general consideration of the "Red Beds."

\section{MARINE ORIGIN OF RED BEDS}

With the main thesis of Branson's paper, that large thicknesses of the red beds of the Rocky Mountain region present characteristics explainable only by the assumption of deposition in a very large body of water, probably saline, the writer has much sympathy. In such formations as the Moenkopi of southern Utah, the undifferentiated Woodside and Thaynes of the eastern Uinta Mountains, and the Chugwater of central Wyoming (where it includes only the beds from the top of the Permian deposits to the base of the "Popo Agie beds" or Jelm formation), the gradual transition laterally from fossiliferous marine red and non-red sediments into unfossiliferous red beds, the widespread regularity and parallelism of bedding in great thicknesses of rock, the lack of coarse materials, etc., do not harmonize well with a postulate of fluviatile origin of the deposits. The contrast is striking between the formations named and such deposits as the Chinle formation, the Jelm formation, and the Dolores formation, in which very irregular bedding, non-persistence of minor units, coarse débris, remains of terrestrial vegetation, crocodiles, dinosaurs, and fresh-water invertebrates suggest a fluviatile origin. Some recent writers have preferred to interpret all red beds as a product of 
"continental" sedimentation, but red beds are so varied in their characters - even in coloring-that a single explanation of origin seems entirely inadequate to account for all of them. One might as well attempt to explain all sandstones by the postulate of a single set of conditions.

\section{CORRELATIONS}

The correlation table given by Branson, ${ }^{\mathrm{I}}$ incorporating in compact form important parts of the paper, seems to the present writer in large part inconsistent with the best existing data. It presents an interpretation much too simple to account for the facts. A large amount of information - of unequal value, to be sure, but mostly usable-has accumulated over a considerable period of years. Recent detailed field work has checked and corrected much of this, has added new data, and has afforded correlations between Utah and western Colorado, between Wyoming and eastern Colorado, between parts of Wyoming, and between southeastern Idaho and adjacent areas in the main so well founded as to seem unimpeachable. The writer has attempted in the following paragraphs to give a brief review of the conclusions reached in this work, together with remarks on some other areas, and has presented them in graphic form in Figure I.

Arizona, southern and eastern Utah, and southwestern Colorado.The section in northern Arizona and southern and eastern Utah has received much attention and is very well worked out. ${ }^{2}$ It may well serve, therefore, as a sort of standard section. That in southwestern Colorado is also well known ${ }^{3}$ and the relations of the formations to

I Ibid., p. 6ro, Fig. 3.

${ }^{2}$ Recent publications on this region include: W. T. Lee and Others, "Possibility of Finding Oil in Southeastern Utah and Southwestern Colorado," U.S. Dept. Interior Memo. for the Press, March 30, 1926; A. A. Baker and Others, "Geology and Oil in Southeastern Utah," U.S. Dept. Interior Memo. for the Press, July 29, I927; A. A. Baker and Others, "Notes on the Stratigraphy of the Moab Region, Utah," Bull. Amer. Assoc. Petr. Geol., Vol. XI (r927), pp. 785-808; James Gilluly and J. B. Reeside, Jr., "Sedimentary Rocks of San Rafael Swell and Some Adjacent Areas in Eastern Utah," U.S. Geol. Surv. Prof. Paper I5O (1928), pp. 61-I10. Many other papers bearing on the region are cited in the papers just listed, among the more important later works being those by Gregory, Emery, Dake, Longwell, Miser, and Prommel.

3 Whitman Cross and Others, U.S. Geol. Surv. Geol. Atlas, Folios 57, 60, I 20, 130, I3I, I53, I7I, and other papers. 
those in Utah are in the main clear, though several lesser points are still in doubt. In the light of the accumulated information now in hand it is difficult to justify the interpretation set forth by Branson in columns 2 and 3 of his Figure 3 .

In northern Arizona and southern Utah the section includes, in ascending order: Moenkopi formation, unconformable chocolate to

\begin{tabular}{|c|c|c|c|c|c|c|c|c|c|c|c|}
\hline & $\begin{array}{l}\text { I' } \\
\text { W.TEXAS } \\
\text { SE.N.MEX }\end{array}$ & $\begin{array}{c}2 \\
\text { NE. } \\
\text { N.MEX. }\end{array}$ & \begin{tabular}{|c|}
3 \\
E.ARIZ. \\
NW.N.MEXX
\end{tabular} & \begin{tabular}{|c|}
4 \\
S.UTAH \\
N.ARIZ. \\
\end{tabular} & $\begin{array}{l}\text { SW. } \\
\text { SW. } \\
\text { COLO. }\end{array}$ & \begin{tabular}{|c|}
$\mathbf{6}$ \\
N. UTAH \\
SW. WYO
\end{tabular} & $\begin{array}{c} \\
\text { SE. } \\
\text { IDAHO }\end{array}$ & $\begin{array}{c}\text { B } \\
\text { NW. } \\
\text { COLO. }\end{array}$ & \begin{tabular}{|c|}
9 \\
CENT. \& \\
S. WYO.
\end{tabular} & $\begin{array}{c}10 \\
\text { NE. } \\
\text { COLO. }\end{array}$ & $\begin{array}{c}\text { II } \\
\text { E. } \\
\text { WYo. }\end{array}$ \\
\hline CRETACEOUS? & & Morrison & & Morrison & Morrison & Morrison & Gannett & Morrison & Morrison & Morrison & Morrison \\
\hline UPPER JURASSIC & & Exeter & Toditio & 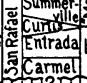 & $\begin{array}{c}\text { mumer- } \\
\text { ville } \\
\text { Pata }\end{array}$ & $\begin{array}{l}\text { Twin } \\
\text { Creek }\end{array}$ & $\begin{array}{l}\text { Stump } \\
\text { Preus } \\
\text { Twin CK. } \\
\text { Twin }\end{array}$ & $=\begin{array}{l}\text { Twin } \\
\text { Creek }\end{array}$ & & & undance \\
\hline $\begin{array}{c}\text { MIDOLL \& LOWER } \\
\text { JURASSIC }\end{array}$ & & & 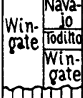 & 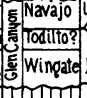 & & \begin{tabular}{|l} 
Nugget \\
Ankareh \\
\end{tabular} & \begin{tabular}{|l|} 
Nugget \\
wod \\
Leadman \\
Hognam \\
rfh?
\end{tabular} & $\begin{array}{l}\text { Nugget } \\
\text { Ankareh? }\end{array}$ & & & \\
\hline UPPER TRIASSIC & Dockum & Triassic & Shinle & Shinle & Dodores & & Timothy & & $\left.\begin{array}{c}\text { (Popo } \\
\text { Apie }\end{array}\right)$ & & \\
\hline MIDDLE TRIASSIC & & & & & & & & & & & \\
\hline LOWER TRIASSIC & & & Moenkopi & Moenkopi & & Woodside & & & En & & jpearfish \\
\hline PALEOZOIC ${ }^{(a)}$ & |Permian & Permian & Permian & $\left.\begin{array}{r}\text { Kalbab a } \\
\text { Coconino }\end{array}\right]$ & ther & ParkCity & Phosphoria & Phosphoria & 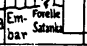 & & $\begin{array}{l}\text { Minnekahta } \\
\text { - peche } \\
\text { Minneluss? }\end{array}$ \\
\hline
\end{tabular}

Fig. I.-Correlation table of Triassic and Jurassic formations of the Plateau region, the Rocky Mountain region south of Montana, and parts of the Great Plains region, as interpreted by John $\mathrm{B}$. Reeside, Jr. The vertically ruled areas indicate absence of sediments. Queries (?) on boundaries indicate doubt as to exact position. In column 3 the small columns (I) and (2) indicate alternative views of correlation. Footnote $(a)$ : Exact equivalence of formations on the line headed Paleozoic is not intended. Footnote $(b)$ : Gannett group probably includes much more than equivalents of Morrison formation.

red-brown, ripple-marked, thinly and evenly bedded sandstone and shale containing marine limestone members that thicken westward, Lower Triassic; Shinarump conglomerate, unconformable sandstone and conglomerate of siliceous pebbles, probably Upper Triassic; Chinle formation, conformable red and greenish sandy mudstone, sandstone, and limestone conglomerate, all irregularly bedded, Upper Triassic; Glen Canyon group, unconformable, probably Jurassic, containing three formations (Wingate sandstone, gray to red, thick, cross-bedded; Todilto(?) formation, thin-bedded red sandstone, 
shale, and minor limestone; and Navajo sandstone, gray-white to light brown, thick, cross-bedded, containing occasional thin limestone lenses); San Rafael group, possibly unconformable, Upper Jurassic, containing four formations (Carmel formation, westward a marine, fossiliferous limestone, shale, and gypsum series, eastward a barren, red, earthy thin-bedded sandstone with bedding contorted; Entrada sandstone, westward a red, earthy, evenly bedded sandstone, eastward a thick, cross-bedded, gray-white to light pinkishbrown sandstone much like Navajo; Curtis formation, westward a light-colored, marine, fossiliferous grit and sandstone, fading eastward into the overlying unit; and Summerville formation, chocolate to red, very thinly and evenly bedded sandstone with crusts of silica); Morrison formation, gray to brown conglomerate and sandstone, and variegated shale containing dinosaur bones, doubtfully Cretaceous.

In southwestern Colorado the section includes, in ascending order: Dolores formation, unconformable, with lithology like that of the Chinle formation, Upper Triassic and possibly Jurassic; La Plata sandstone, unconformable, with lithology much like that of Navajo and Entrada and containing a thin limestone member near the middle, Jurassic; "McElmo" formation of the literature, unconformable, with basal part red and now assigned to the Summerville, and with upper part now assigned to the Morrison.

The Moenkopi formation does not extend into Colorado. The Shinarump conglomerate, Chinle formation, Wingate sandstone, and Todilto(?) formation seem to occupy the interval of the Dolores formation and were so identified by Cross, though some difference of opinion now exists as to whether Wingate and Todilto(?) extend as far eastward as the typical area of the Dolores, and it may be found equivalent there to Shinarump and Chinle only. The La Plata sandstone of Colorado, originally traced into eastern Utah by Cross and identified by him as including the three formations now named Navajo, Carmel, and Entrada, is seemingly the equivalent of these sandstones, though there is some doubt that the Navajo extends as far eastward as the area of the typical La Plata sandstone, and it may be found chiefly equivalent there to Entrada. Branson recognizes only two large sandstone units, though there are three, and 
correlates them with the Vermilion Cliff group of Powell, which is, however, only the Wingate sandstone. The base of the Shinarump, the base of the Chinle where Shinarump is not recognized, and the base of the Dolores mark a widespread unconformity, the significance of which has been completely missed by Branson. The beds immediately beneath it belong to the Lower Triassic Moenkopi formation in east-central Utah and to the Permian Cutler formation in extreme eastern Utah and western Colorado. The Shinarump is conformable with the Chinle formation, which contains, as does the Dolores, vertebrate and fresh-water invertebrate remains usually accepted as Upper Triassic. Strong angular discordance at some localities beneath the Shinarump, and Chinle where Shinarump is not recognized, serves to strengthen sharp differences in lithology and fauna and makes it highly probable that a considerable time interval, perhaps most of the Middle Triassic, is unrepresented in the section. The La Plata sandstone has always been considered Jurassic, an assignment now definitely established for the part found equivalent to the Entrada sandstone (possibly the whole in the San Juan Mountains in Colorado). The age of the Glen Canyon group is not definitely determinable, though its resemblances are with the overlying Upper Jurassic much more than with the underlying Upper Triassic. Its known fossils include, in addition to dinosaur tracks, several species of Unio and some indeterminate plant remains, possibly ferns. Such structural evidence as there is agrees with lithology in associating the group with the later rather than with the earlier deposits, and its age is therefore stated as Jurassic(?). The writer believes the group best placed in the Jurassic without query and has so shown it in Figure I.

Eastern Arizona and northwestern New Mexico.-The relations between northern Arizona, on one hand, and eastern Arizona and western New Mexico, on the other, are somewhat in question. There seems to be valid Moenkopi in the latter area, ${ }^{\mathrm{x}}$ and a representative of the Shinarump and Chinle formations; but there is ground for doubt that the Wingate and Todilto(?) formations of northern

${ }^{1}$ N. H. Darton, "A Résumé of Arizona Geology," Ariz. Bur. Mines Bull. IIg (I925), pp. IIO, II7; "A Reconnaissance of Parts of Northwestern New Mexico and Northern Arizona," U.S. Geol. Surv. Bull. 435 (1910), pp. 32-54; H. E. Gregory, "Geology of the Navajo Country," U.S. Geol. Surv. Prof. Paper 93 (1917), pp. 27, 28. 
Arizona are exact equivalents of the typical Wingate sandstone and Todilto limestone of eastern Arizona and northwestern New Mexico, and as to what part of the Utah sequence is equivalent to the Navajo and "McElmo" formations of northwestern New Mexico. More field study is needed before these points can be cleared up. As matters stand now, the Carmel formation of northern Arizona has been correlated through southeastern Utah with a limestone member in the middle of the La Plata sandstone of southwestern Colorado; and this limestone member in turn, with the Todilto limestone of north-

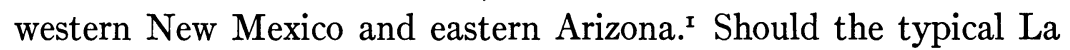
Plata prove to be equivalent to Entrada, the Arizona equivalent of the limestone would be still higher in the section. On the other hand, the Todilto(?) formation of northern Arizona has also been correlated directly with the Todilto limestone of eastern Arizona. ${ }^{2}$ The Todilto(?) formation and the Carmel formation, separated by the Navajo sandstone, cannot both be equivalent to the Todilto limestone; and until some settlement is reached, the correlation of the other formations of the section must stand in doubt.

Eastern Arizona and northwestern New Mexico.-The correlation of the Dockum group ${ }^{3}$ of Texas-unconformable red clays, greenishgray sandstone, and conglomerate, irregularly bedded and containing reptilian remains, fresh-water invertebrates, and fossil woodwith the Chinle formation, accepted by Branson, appears to be well founded. That any representatives of the Glen Canyon group (Wingate, Todilto[?], and Navajo) exist in western Texas and southeastern New Mexico seems, on the other hand, very doubtful in the light of present information, but is certainly not excluded. In northeastern New Mexico the Exeter sandstone rests unconformably on Triassic red beds and was correlated by $\mathrm{Lee}^{4}$ with the Wingate sandstone.

${ }^{1}$ N. H. Darton, "Red Beds in New Mexico," U.S. Geol. Surv. Bull. 794 (in press); W. T. Lee, "Early Mesozoic Physiography of the Southern Rocky Mountains," Smithsonian Misc. Coll., Vol. LXIX (1918), No. 4, pp. 18-21; H. E. Gregory, op. cit., p. 52, pl. 3 .

${ }^{2}$ H. E. Gregory, op. cit., pp. 55, 56.

3 For description and other references, see H. W. Hoots, "Geology of a Part of Western Texas and Southeastern New Mexico," U.S. Geol. Surv. Bull. 780 (1926), pp. 86-96.

${ }^{4}$ W. T. Lee, "The Morrison Shales of Southern Colorado and Northern New Mexico," Jour. of Geol., Vol. X (I902), p. 45; "Early Mesozoic Physiography of the Southern Rocky Mountains," Smithsonian Misc. Coll., Vol. LXIX (Iq18), pp. 22-24. 
Darton $^{\mathrm{I}}$ considers it a member of the Morrison formation. Stanton ${ }^{2}$ records 200 feet of Morrison in conformity above it, and red beds unconformably beneath it. DeFord ${ }^{3}$ has recently recorded the presence of Exeter in western Oklahoma conformably beneath Morrison and unconformably above variegated shales and red beds. In Figure I the writer has placed Exeter as close to Morrison but perhaps somewhat older.

Northern Utah and southeastern Idaho.-The typical Woodside, Thaynes, and Ankareh formations ${ }^{4}$ of northern Utah, named in ascending order, have usually been placed in the Lower Triassic, chiefly on the basis of the marine invertebrates in the Thaynes, though the Ankareh is now doubtfully classified as Triassic. The Woodside is a dark-red shale; Thaynes, an alternation of gray and blue limestones with gray and red shales and minor sandstones; and Ankareh, red sandy shales and gray sandstones. Above lie thick, light-colored Nugget sandstone and the Upper Jurassic marine Twin Creek limestone. In a paper read before the Paleontological Society of America at Cleveland in December, 1927, A. L. Mathews reported new data on these formations which may be stated as follows: In the Wasatch Mountains near Salt Lake City the Woodside shale, containing nonmarine strata below and marine. Lower Triassic above, rests unconformably on the underlying Phosphoria formation (Permian) and passes up without break into the overlying beds. These are divided into two lithologic units- the lower with a large marine Lower Triassic fauna; the upper with a smaller fauna, including the genus Daonella, apparently of Middle Triassic age. This upper unit includes apparently much of the typical Thaynes of Boutwell, part of the lower unit not appearing at the type locality. The unfossiliferous Ankareh formation is unconformable upon the Thaynes and is placed doubtfully in the Upper Triassic. A sand-

I N. H. Darton, personal communication.

${ }^{2}$ T. W. Stanton, "The Morrison Formation and Its Relations with the Comanche Series and the Dakota Formation," Jour. of Geol., Vol. XIII (I905), p. 665.

3 R. K. DeFord, "Areal Geology of Cimarron County, Oklahoma," Bull. Amer. Assoc. Petr. Geol., Vol. XI (I927), p. 753.

${ }^{4}$ J. M. Boutwell, "Stratigraphy and Structure of the Park City Mining District, Utah," Jour. of Geol., Vol. XV (1907), pp. 434-58; "Geology and Ore Deposits of the Park City District, Utah," U.S. Geol. Surv. Prof. Paper 77 (I9I 2), pp. 52-59. 
stone formation that begins with a well-defined basal conglomerate and is probably equivalent to the Nugget yielded a marine fossil and tentatively is assigned to the Lower Jurassic. The Twin Creek formation rests on this sandstone with apparent conformity.

The Lower Triassic fauna of the Thaynes formation occurs also in equivalent beds in southeastern Idaho ${ }^{\mathrm{I}}$ and in much less extensive development in the Moenkopi formation of southern Utah. ${ }^{2}$ The section given by Mansfield for southeastern Idaho is, in ascending order, as follows: Woodside shale, unconformable alternating olivedrab shale and brownish-gray fossiliferous marine limestone, Lower Triassic; Thaynes group, conformable, marine fossiliferous, Lower Triassic, containing three formations (Ross Fork, limestone, shale, and sandstone; Fort Hall, yellowish sandstones below, olive-drab shales above; Portneuf, olive-drab limestones with some red sandstone and shale); Timothy sandstone, unconformable yellowish, locally reddish, sandstone containing local conglomeratic beds and obscure plant remains, doubtfully Lower Triassic; three doubtfully Triassic formations, unconformable Higham grit, Deadman limestone, and Wood shale, the latter red and gypsiferous; possibly unconformable Nugget sandstone, Jurassic; Twin Creek limestone, unconformable, fossiliferous marine, Upper Jurassic and possibly in part Middle Jurassic; Preuss sandstone, unconformable, barren; Stump sandstone, conformable, fossiliferous marine, Upper Jurassic; Gannett group, unconformable, nonmarine, possibly Lower Cretaceous.

Unless the Timothy sandstone with its plant remains and its conglomerates represents the interval of the Chinle and the Shinarump, there is no clear evidence of the presence in northern Utah and southeastern Idaho of the widespread Upper Triassic deposits. It seems to the writer that the best present interpretation is to correlate the Timothy sandstone with the Shinarump and Chinle and assign it to the Upper Triassic, and to correlate the Higham, Dead-

I G. R. Mansfield, "Geography, Geology, and Mineral Resources of Part of Southeastern Idaho," U.S. Geol. Surv. Prof. Paper I52 (1927), pp. 84-96, 373-76.

2 J. B. Reeside, Jr., and Harvey Bassler, "Stratigraphic Sections Southwestern Utah and Northwestern Arizona," U.S. Geol. Surv. Prof. Paper 129 (1922), pp. 59-62, $67-68$. 
man, and Wood with the Ankareh and consider them as closely associated with the Nugget sandstone and probably of Jurassic age. There has been some confusion in the use of the name Ankareh, as demonstrated by Mansfield, ${ }^{\mathbf{x}}$ and some difference of opinion as to its relations with adjacent formations, though the most recent data seem to warrant a reversion to the original concept of Ankareh as closely related to Nugget. The Nugget sandstone itself approaches in character very closely the Navajo and Entrada sandstones of southern Utah and the basal sandstone of the Sundance of Wyoming. ${ }^{2}$

Northwestern Colorado.-In the eastern Uinta Mountains in northwestern Colorado ${ }^{3}$ the section contains in ascending order: undifferentiated Woodside and Thaynes(?) ${ }^{4}$ formations, apparently conformable red, locally gray and drab, shale, minor sandstone and limestone, unfossiliferous, Lower Triassic; Ankareh(?) ${ }^{4}$ formation, unconformable grit, sandstone, and red and gray sandy shale; Nugget sandstone, conformable, thick, white and gray, cross-bedded, Jurassic; Twin Creek limestone, conformable, fossiliferous marine limestone and shale, Upper Jurassic; Morrison formation, doubtfully Cretaceous. The evidence of such tracing as is possible, stratigraphic position, structural relations, and lithology makes the continuity of the Woodside and Thaynes(?) of the eastern Uintas with the Woodside and Thaynes of the western Uintas very nearly certain, though a paleontologic tie is not available, and division into units in the east does not seem feasible. The Ankareh(?) formation of the eastern Uintas seems to correspond best to the Ankareh formation of the western Uintas and is most logically viewed as introductory to the

IOp. cit., p. 82.

${ }^{2}$ W. T. Lee, "Correlation of Geologic Formations between East-central Colorado, Central Wyoming, and Southern Montana," U.S. Geol. Surv. Paper 149 (1927), pp. I5-I7.

${ }^{3}$ J. D. Sears, "Geology and Oil and Gas Prospects of Part of Moffat County, Colorado, and Southern Sweetwater County, Wyoming," U.S. Geol. Surv. Bull. 75 I (1924), pp. 277, 280, 284; J. B. Reeside, Jr., "Notes on the Geology of Green River Valley between Green River, Wyoming, and Green River, Utah," U.S. Geol. Surv. Prof. Paper I 32 (1923), pp. 38, 40, 43, 45, 48; A. R. Schultz, "Oil Possibilities in and around Baster Basin, in the Rock Springs Uplift, Sweetwater County, Wyoming," U.S. Geol. Surv. Bull. 702 (1920), tables opp. pp. 24, 36.

${ }_{4}$ Branson, in quoting Sears, omits the queries. 
Nugget. The Nugget sandstone itself, on its lithology and structural relations, seems best correlated with some part of the NavajoEntrada sequence and, as Lee suggests, ${ }^{\mathrm{I}}$ with the basal sandstone of the Sundance formation of Wyoming, though again a paleontologic tie is not available.

Wyoming.-The Chugwater formation at its type locality in southeast Wyoming by definition ${ }^{2}$ included all of the red beds in the section between the Pennsylvanian Tensleep sandstone and the Jurassic Sundance formation. In extending the use of the name, a similar interpretation was often put upon it, to the effect that there were lumped together various red beds-from those demonstrably Permian to those demonstrably Upper Jurassic in age-ignoring various differences in lithology, unconformities, fossil content, etc. Branson has accepted this concept, unfortunately with considerable confusion to the reader, for there is a general lack of specification, when the term "Chugwater" is used, as to what part of the assemblage of different sorts of rock is meant. In several areas the Permian part of the "Red Beds" has been separated from the Chugwater and given distinctive formation names, and the Chugwater formation has been further restricted by the removal of the Jelm ("Popo Agie") formation at the top. Lee ${ }^{3}$ has recently discussed these and other subdivisions. Brainerd and Keyte ${ }^{4}$ have also called attention to the desirability of separation of the upper part. On the basis of personal observations and the printed record it seems to the writer most logical to divide the "Red Beds" into four divisions: (I) a basal unit of interbedded Permian red beds and minor limestones, including the Forelle limestone and Satanka shale and passing westward into the Phosphoria formation and northward into the Embar formation; (2) an apparently conformable, though probably unconformable, unit of red beds with minor limestone members, Lower

${ }^{1}$ U.S. Geol. Surv. Prof. Paper 149 (1927), p. I6.

${ }^{2}$ N. H. Darton, "Comparison of the Stratigraphy of the Black Hills, Bighorn Mountains, and Rocky Mountain Front Range," Bull.Geol. Soc. Amer., Vol. XV (1904), p. 397.

3 W. T. Lee, U.S. Geol. Surv. Prof. Paper 149 (1927), pp. Io-r6.

4 A. E. Brainerd and I. A. Keyte, "Some Problems of the Chugwater-Sundance Contact in the Bighorn District of Wyoming," Bull. Amer. Assoc. Petr. Geol., Vol. XI (1927), pp. 747-52. 
Triassic and possibly in small part Middle Triassic, the basal part passing westward into the Dinwoody formation; (3) the unconformable nonmarine Jelm ("Popo Agie beds"), absent at some localities; (4) the unconformable basal sandstone of the Sundance and the overlying red beds of the Sundance.

The writer believes with $\mathrm{Lee}^{\mathrm{x}}$ that the Jelm and "Popo Agie beds" are essentially the same; that they are unconformable on the underlying beds, the unconformity representing much of the Middle Triassic and possibly part of Upper Triassic time; that the differences in the scanty vertebrate faunas are more likely due to the accidents of preservation and of collecting than to difference in age; and that the structural relations, stratigraphic position, and lithology must be considered of superior weight. It seems to the writer that Branson is inconsistent in discarding the evidence of the vertebrates, ${ }^{2}$ while using the differences in the recorded vertebrate faunas of the "Popo Agie beds" and the Jelm formation to support the interpretation of difference in age. ${ }^{3}$

The writer believes that the name Chugwater would best be restricted to the part of the red beds between the Permian and the base of the Jelm ("Popo Agie"), wherever these limits can be drawn. This is in accord with the present practice of the U.S. Geological Survey, which is to place the top of the Chugwater at the base of the Jelm ("Popo Agie"), where that unit is recognized, and excludes from the Chugwater the Dinwoody, Embar, Phosphoria, Forelle, and Satanka formations wherever any of these are recognized. In some areas, notably the east side of the Bighorn Mountains, where the foregoing units have not been differentiated, Chugwater is still used to include rocks of Permian age. The red beds of Upper Jurassic age have always been excluded from the Chugwater where recognized as such by their invertebrate fossils. The upper boundary of the Chugwater, as thus defined, is at many places not far above the top of the Alcova limestone. It seems at least highly probable that the marine Dinwoody formation grades eastward into the lower Chugwater (as thus restricted) and this feature, together with the occurrence of the marine Alcova limestone near the top and the physical character-

${ }^{\prime}$ W. T. Lee, U.S. Geol. Surv. Prof. Paper 149 (1927), p. I4.

\footnotetext{
2 E. B. Branson, op. cit., p. $6 \mathrm{I} 6$.

${ }^{3}$ Ibid., p. 615.
} 
istics of the intermediate sediments, make plausible the assumption of marine origin for this part of the red-bed sequence. The so-called "upper Chugwater red beds" above the "Popo Agie beds" near Lander, Wyoming, cited by Branson as of marine origin and therefore indicating a position for the "Popo Agie beds" below that of the Jelm formation ${ }^{\mathrm{x}}$ are in the writer's opinion merely the widespread lower Sundance (Upper Jurassic). These beds do contain at places marine fossils, specifically in a zone between the basal sandstone and the overlying red beds, and the red beds themselves have bedding and other features similar to those of the Chugwater (restricted); but the fossils are Upper Jurassic and therefore the beds have little bearing on the relations of "Popo Agie" and Jelm to the Chugwater.

Black Hills and eastern Colorado.-Branson interprets the Spearfish formation of the Black Hills to follow the Lykins formation of the foothills of the Front Range of Colorado directly in time. The Lykins formation has been described most recently by Henderson ${ }^{2}$ and Lee, ${ }^{3}$ and the Chugwater of the nearby area in Wyoming by Lee and Darton and Siebenthal; $;^{4}$ and it seems to the writer that the Lykins contains the restricted Chugwater and also some Permian beds at the base. Lee thought he saw a thin representative of the Jelm formation at some places-a suggestion to which earlier reports of Upper Triassic vertebrates in Colorado lend credibility. The Spearfish formation and underlying Minnekahta limestone $\mathrm{e}^{5}$ are not so easily assigned. The Spearfish seems to be of the same type of red beds as the Chugwater (restricted) and would on that ground be essentially Lower Triassic. The Minnekahta limestone occupies a place in the section that appears to correspond to that of the Forelle limestone (Permian) of southern Wyoming, though the fossils of the

I Ibid., pp. 6r4, 6r7.

${ }^{2}$ Junius Henderson, "The Foothills Formations of North-Central Colorado," Colo. Geol. Surv. Bull. 19 (1920), pp. 76-78.

3 W. T. Lee, U.S. Geol. Surv. Prof. Paper 149 (1927), p. то.

${ }^{4}$ N. H. Darton, Eliot Blackwelder, and C. E. Siebenthal, "Laramie-Sherman Folio," U.S. Geol. Surv. Geol. Atlas, Folio I73 (1910), pp. 7-8. Branson (p. 6II) credits this folio to Blackwelder, who wrote only the parts concerning the pre-Cambrian.

5 N. H. Darton and Sidney Paige, "Central Black Hills Folio," U.S. Geol. Surv. Geol. Atlas, Folio 219 (1925), pp. 9, то. 
Minnekahta are more like those of the Alcova limestone. ${ }^{\mathbf{x}}$ All three limestones are curious, minutely-banded and colored "ribbon" limestones. If the Minnekahta is equivalent to the Alcova, the Spearfish is equivalent to Jelm and of Upper Triassic age. The eastward overlap of Upper Triassic over Lower in Utah and Colorado would offer a parallel for such a situation. On the other hand, there is very little warrant for a correlation of Spearfish and Jelm on faunal or physical grounds, and very little warrant in general for the supposition that any Upper Triassic beds exist in the Black Hills region. Nearly everything known about Spearfish and much of the Lykins links them both with the Chugwater (restricted) and seems to the writer directly against the interpretation that Lykins precedes Spearfish in time.

\section{SEPARATION OF UPPER AND LOWER "RED BEDS"}

Concerning the separation of the lower from the upper "Red Beds" in the Rocky Mountain region, the foregoing discussion of local sections and correlations indicates that several divisions in the Mesozoic part of the sequence are both possible and desirable. In brief repetition these divisions are: (I) A widespread unit, in the main Lower Triassic, but at one locality reported as extending somewhat into the Middle Triassic and possibly also at other localities where evidence is now lacking. It is separated from the preceding Permian beds, in part red beds, by a hiatus. Westward it includes a progressively increasing proportion of fossiliferous marine beds, and eastward, though unfossiliferous, at least indicates deposition in a large body of water. (2) An Upper Triassic unit, widespread in the south but possibly sporadic in occurrence in the north. It is separated from the preceding beds by a hiatus which corresponds to much of Middle and perhaps part of Upper Triassic time. It bears everywhere evidence of fluviatile origin. (3) A Jurassic unit representing part of Upper Jurassic time and an undetermined part of older Jurassic time, and separated from the preceding beds by a hiatus. This unit begins with large sandstones, which have yielded a few non-marine fossils and are in part subaerial in origin, and then passes into marine deposits, in part red, which have yielded Upper Jurassic fossils.

${ }^{\mathrm{I}} \mathrm{G}$. H. Girty, personal communication. 


\section{EOLIAN DEPOSITS}

Regarding the question of the formation of eolian deposits during the time interval covered by the term "red beds" in its larger sense -from Permian to Upper Jurassic and including such formations as the basal sandstone of the Sundance, the Nugget sandstone, the Glen Canyon Group, the La Plata sandstone, etc.-Branson decides that there were no eolian deposits of any importance whatever, and that the "Red Beds" are marine deposits and subaerial delta materials. He says of the large, cross-bedded, chiefly non-red sandstones:

The La Plata, Navajo, and Wingate have none of the qualities of subaerial deposits. They are in the main thick bedded, and some of the beds are remarkably thick. The thick beds are usually cross-bedded, in part foreset beds of deltas. The beds do not change abruptly in composition. One may trace them for many miles without being able to detect any change in texture or thickness of beds. Ripple marks are common. No land fossils have been found save a so-called dinosaur footprint in the Todilto, which lies between the Wingate and Navajo and seems to be of the same origin. ${ }^{\mathrm{I}}$

At another place:

Perhaps the question of the possible eolian origin of considerable parts of the Wingate, Navajo, La Plata, and Chugwater should not be dismissed as summarily as by Twenhofel. . . . The writer is in agreement with Twenhofel in considering such an origin as clearly impossible. Winds do not create widespread beds of even thickness; wind deposits are not ripple marked on extensive surfaces; extensive wind deposits vary greatly in texture from coarse, wellrounded almost pure quartz sand, on the one hand, to heterogeneous loesslike deposits, to fine silt deposits. It has been rather generally assumed that wind deposits should have well-rounded grains and be uniform in texture and composition. This is true of the fairly coarse wind-blown sands, but where the modal grains are less than $\frac{1}{4} \mathrm{~mm}$. in size the materials are highly heterogeneous and the grains are mainly angular. . . . . In an area of deposition as large as that covered by the Wingate, Navajo, or any of the red bed sands, the fine dune sand, loess, and adobe should be much larger in amount than the coarse dune sand, but the sands of all these formations are remarkably well sorted. ${ }^{2}$

The writer would agree with Branson that the red beds proper, i.e., excluding the large sandstone formations, give little evidence of eolian origin; further, that parts of the large, cross-bedded sandstones, in part red but chiefly non-red, are by most of our ordinary

$$
{ }^{2} I b i d ., \text { p. } 627 . \quad \quad{ }^{2} I b i d ., \text { pp. } 629,630 .
$$


criteria water-laid. On the other hand, to say on the basis of present data that eolian origin or, in larger terms, subaerial origin is "clearly impossible" for a considerable part of the large sandstone formations, does not appear to be justified. It is premature to settle so important and complex a question in this out-of-hand fashion and on purely theoretical grounds. When much more first-hand information is available than anyone has yet given evidence of possessing, we may hope for a definite answer regarding the origin of this imposing part of the Mesozoic sequence. In the meanwhile a reserved judgment would seem to be the safer and wiser attitude. The gross characters of the sandstones in question have been given by description and photograph in many papers and it seems of little service to repeat them here. Suffice it to say that Branson's picture of them does not seem to the writer entirely accurate. There are certain planes that can be followed over large areas, it is true, but they are few and the thicknesses of rock between, in which very large-scale tangential cross-bedding is conspicuous, are large. In the Navajo particularly is this true. Here and there in the Navajo are "pans" of sandy limestone, a small fraction of a mile in diameter and a few feet thick, often containing thin sheets which were cracked and curled by drying and then covered by sand, the sand now filling the cracks around the sharp-edged and "unwilted" curls. At at least one locality the Navajo contains perfectly typical dreikanter. The writer has not seen extensive, flat, ripple-marked surfaces anywhere in the large sandstone formations (except possibly in some thin water-laid parts and in the Todilto(?), where also occur shells of Unio and vegetable débris) in fact, ripple marks are unusually rare-and the writer suspects in Branson's statements a confusion with some of the possibly marine red beds. Footprints have been observed in other parts of the sequence in addition to the Todilto(?). In short, the mass of evidence seems against the theory of marine origin set forth by Branson, and there is a considerable amount in favor of subaerial and even of eolian origin. The writer is led to wonder whether the characters of extensive wind deposits, as given in the second quotation above, are sufficiently well founded to fix the criteria by which we must judge all deposits of all geologic time. The supposed absence of presentday eolian deposits of extent and thickness comparable to those of 
these ancient sandstones is an unconvincing argument, and the theoretical improbability of the wind's being able to build such formations does not seem to the writer to preclude such an origin. The deposits themselves seem to the present writer to have on a grand scale the characteristics of present-day small-scale eolian formations. At any rate, a more or less perfunctory dismissal of the question serves no useful purpose.

\section{PALEOGEOGRAPHY}

Branson's paleogeographic map of Upper Triassic time (his Fig. 2) would be difficult to defend. The beds accepted as definitely Upper Triassic in the area shown as sea from eastern Nevada eastward are all nonmarine, probably fluviatile deposits. The marine and probably marine red beds known are in greater part Lower Triassic, in lesser part Upper Jurassic, but none are Upper Triassic. The great river system is based on the interpretation of Dockum, Chinle, etc., as delta materials interfingering with the marine deposits - an untrue assumption, for there is no known interfingering, but on the contrary widespread sharp separation. In western Nevada and in the Pacific states, marine Upper Triassic occurs, ${ }^{\mathrm{I}}$ but there is no known connection with the non-marine Upper Triassic beds of the region farther inland.

\section{CONCLUSIONS}

In summary, the present writer would agree with Branson that part of the sequence of red-bed formations in the Rocky Mountain region may be marine and that part is certainly non-marine. He disagrees with much of Branson's correlation table, particularly the conclusion that there is no basis for subdivision of the red beds, and finds three widespread units present, in age essentially Lower Triassic, Upper Triassic, and Jurassic. The Permian red beds constitute a fourth unit. He believes that the lower part of the Jurassic unit contains important eolian deposits, and that the paleographic map of Upper Triassic time is invalid because based on an erroneous interpretation of the stratigraphy.

I J. P. Smith, "Upper Triassic Marine Invertebrate Faunas of North America," U.S. Geol. Surv. Prof. Paper I4I (1927), pp. 2-13. 